\title{
Transformation of Cycles of State Regulation in International Trade
}

\author{
Viktor Koval \\ Odessa Institute of Trade and \\ Economics \\ Kyiv National University of Trade and \\ Economics \\ Odessa, Ukraine \\ victor-koval@ukr.net \\ Iryna Kvach \\ Odessa Institute of Trade and \\ Economics \\ Kyiv National University of Trade and \\ Economics \\ Odessa, Ukraine \\ Ikvach1994@gmail.com
}

\author{
Liudmyla Prystupa \\ Department of Economics and \\ Management \\ Khmelnytskyi National University \\ Khmelnytskyi, Ukraine \\ PrystupaLA@gmail.com
}

\author{
Andrei Hrymalyuk \\ Odessa Institute of Trade and \\ Economics \\ Kyiv National University of Trade and \\ Economics \\ Odessa, Ukraine \\ andreigrim01@gmail.com
}

\begin{abstract}
The article illustrates a natural character of contemporary change processes happening in world economy related to cyclic development of international trade and its state regulation. The purpose of the article is to justify the cyclical nature of the evolution of state regulation of international trade. The object of the article is the regular connection of state regulation with the historical evolution of international trade. The methodological basis of the study is scientific methods, in particular the dialectical method and the methods of cyclic analysis, aimed at finding cyclical patterns of the historical process of the development of international trade. The analysis conducted in article shows that now the world economy is on the threshold of the new historical cycle, which can begin as the globalization crises persisted along with the transition of the increasing number of countries to protectionist regulation of international trade.
\end{abstract}

Keywords-regulation, deregulation, international trade, protectionism, economic liberalism, cyclical nature.

\section{INTRODUCTION}

Due to the updating of the state development strategies there is a need to mainstream the existing measures of state regulation for social and economic development and elaborate a new effective investment mechanisms for regions growth, which should be considered in wider context of global processes.

Especially as in literature such aspects of a problem, involved in global surplus of savings and economic mechanisms of its investment use aren't always considered and respectively aren't completely taken into consideration during formulation and scientific justification of foreign trade development strategies.

Besides the balance of development in all regions with the repeating economic regularity acquires special relevance, which is associated with the cyclic nature of state regulation evolution of trade.

\section{LITERATURE REVIEW}

The extensive literature covering a wide range of both theoretical and practical aspects of these problems is devoted to questions of state regulation of investments in trade.

Globalization processes of world economy for the extended period are characterized by insignificant slowing down of development, the relative strengthening of a role of national instruments of economic regulation for elimination of those imbalances, disproportions and asymmetries which arose during rapid development of globalization. The neoliberal globalization has run out resources and further can't develop efficiently that directly influences trade policy of the developed countries.

In this regard, investors from the developed countries need to send investments into less competitive countries that can improve climate for direct foreign investments. Therefore, the investment break is possible for the developed countries and capable to bring new historically important results of the advancing development, promote strengthening of their political and competitive global leadership in the $21 \mathrm{st}$ century.

Prerequisite of it is the global solidarization of the USA with the partner countries and the transitive nations, including Ukraine [1]. In the course of this discussion, Galchynsky and Geyets [1] made a significant contribution to the development of specific proposals aimed at stimulating a way out of the crisis and ensuring the further development of the national economy. These circumstances need to be fully taken into account when considering those discussions, which were developed, in domestic economic literature in connection with searching of paths of further development of Ukraine. During this discussion, the works [2] offer the directions of incentive for recovery from the crisis and ensuring further development of national economy and trade.

However, in recent years the subject of a scientific discussion began to be displaced in the direction of searching 
of the versions of "the new plan of Marshall" considered in a wide historical context of global changes, connected with crisis of globalization and the prospects of deep structural transformation of all system of the international economic relations. In study [3], the main one in this study is the substantiation of the features of the modern historical stage in the development of international trade and state regulation.

In relation to works on the theory of international trade with a research of cyclic nature of state regulation of foreign trade, the main works are [4], [5]. These studies show the increasing role of national instruments of economic regulation for eliminating the imbalances, imbalances and asymmetries in international trade that arose during the period of rapid development of globalization. The study [5], [6] analyzes the state of international trade on the basis of empirical data on the development of the global economy, as in emerging markets.

Therefore, the purpose of article is justification of cyclic approach to the analysis of evolution of state regulation of international trade.

\section{UNRESOLVED PART OF THE RESEARCH PROBLEM.}

It should be noted that most of the fundamental works on the theory of international trade in recent years have become increasingly formalized, which, of course, expresses the influence of the neoclassical trend [4] - [8]. As you know, neoclassic categorically rejects the principle of historicism in economic theory. The place of analysis of the specific features of international trade in various historical eras, including the modern stage of development, is occupied by the construction of conditional non-historical models claiming universality. As a result, the analysis of the laws of the historical evolution of international trade is actually taken out of the theory. The evolution of international trade and government regulation appears simply as a stream of events that is not subject to theoretical understanding. At the same time, it is overlooked that this evolution is in a certain sense cyclical in nature and consists essentially of a series of sequential historical cycles related to the alternation of active state regulation and liberal deregulation of foreign trade. As a result, the most important research problem of searching for cyclical patterns of the development of international trade and state regulation remains virtually unresolved in the literature.

\section{THEORETICAL BASES AND METHODS}

Theoretical principles of article form the economic concepts, which made decisive impact and in many respects determined foreign trade policy of the most developed countries. The most important theoretical principles of article is the classical theory of international trade, which consistently was developed by classical school.

Besides, in article some aspects of the neoliberal theories are taken into account, which in a sense form theoretical bases of article as they keep the influence on trade policy of the advanced countries even in the modern conditions of crisis of the liberal globalization.

At the same time it is necessary to notice that as in article, mainly, historical evolution of theories of international trade is considered, theoretical principles of article serve as an immediate unity with historical analysis.

\section{EVOLUTIONARY CYCLE OF REGULATION AND DEREGULATION OF INTERNATIONAL TRADE}

The prevailing mercantilism proving the active state policy of trade protectionism involving not only protection of domestic market, but also inducing of export productions development. However, as opposed to policy of the foreign trade protectionism there is a theory of the spontaneous mechanism of international trade incompatible with protectionism [6].

The mechanism operates without participation of the state and doesn't demand any regulation of economy, especially such active regulation which was offered by mercantilism on the basis of which the transition from protectionism to the free trade was justified.

The economic liberalism that is minimizing the state intervention in economy based on the mechanism of the market competition is characterized by the fact that everything does the market itself and doesn't need the active regulation from the state, but assumes only the state function - the protection of private property [7].

Division of labor increases its efficiency, and then division of labor moves to the international level, as a result international trade is capable to increase the income of all participants. But for this purpose, according to Smith [7], the total rejection of mercantilism and transition to free trade is needed.

Further development of classical liberal justification of free trade is related to the principle of comparative advantages that allows to reach effect of international trade for all participants.

However, the static nature of the liberal theories of the free trade, related to the competitive advantage, which is already available at the moment. Nevertheless, not only use of already available competitive advantages in international trade is important, but also the creation of these advantages. If the country lagged behind others in the economic development, it should close the market for import goods for the sake of competitive advantages creation, having temporary free trade refusal. Only when such policy of "educational protectionism" will lead to creation of competitive advantages, it is possible to open the market and to pass fully to the free trade to use these advantages created by it.

\section{The SECOND CyCLE AND PROSPECTS OF THE NEW CYCLE OF INTERNATIONAL TRADE}

Emergence of large monopolies in economic structure of the industrial countries at the beginning of the XX century contributed to return of the developed countries to policy of trade protectionism. The use of protectionism stimulated transition to new historical cycle in development of international trade and its state regulation.

But in the conditions of globalization the tendency to the free trade started as protectionist policy led to "trade wars" between the leading industrial countries that is related to fight for sales markets and sources of raw materials.

The second two-phase historical cycle by the end of the 20 th century is characterized by decrease of the active state regulation and the liberal deregulation of international trade. 
However at the beginning of 21 st century the symptoms of the termination of this neoliberal phase of international trade development are increasing, related to globalization of economy.

The most important factor of crisis of globalization is the neomercantilist policy of China, which for the last decades artificially underestimates by currency interventions yuan exchange rate against the dollar to make the Chinese goods cheaper and to increase their competitiveness in the world market. In result, the permanent surpluses of the Chinese trade balance are interconnected with deficit of the American trade balance [8].

In the table 1 the deficit of the American trade balance is presented in a global context in dynamics for several years. Special attention is attracted by quite natural combination of trade deficit of the USA with trade surplus of China and trade surplus of the EU and Germany. Against the background of these obvious imbalances increase of trade deficit of Ukraine have especially disturbing view. In general, the table shows the dangerous unbalance of the international flows of goods, meaning such imbalance of world trade, which quite can lead to trade wars in the nearest future.

TABLE I. TRENDS IN EXPORT AND IMPORTS VOLUME OF TRADE FROM 2015 TO 2017 (IN TRILLIONU.S. DOLLARS)

\begin{tabular}{|c|c|c|c|c|c|c|}
\hline \multirow[t]{2}{*}{ Region } & \multicolumn{2}{|c|}{2015} & \multicolumn{2}{|c|}{2016} & \multicolumn{2}{|c|}{2017} \\
\hline & 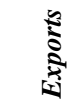 & 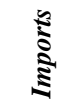 & 文 & ڤ్ & 屁 & 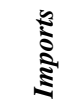 \\
\hline World & 16.41 & 16.56 & 15.89 & 16.04 & 17.59 & 17.83 \\
\hline $\begin{array}{l}\text { European } \\
\text { Union } \\
\text { (EU 28) }\end{array}$ & 5.27 & 5.12 & 5.22 & 5.12 & 5.72 & 5.64 \\
\hline $\begin{array}{l}\text { United } \\
\text { States of } \\
\text { America }\end{array}$ & 1.50 & 2.31 & 1.45 & 2.25 & 1.55 & 2.41 \\
\hline China & 2.27 & 1.68 & 2.10 & 1.59 & 2.26 & 1.84 \\
\hline Germany & 1.33 & 1.06 & 1.34 & 1.06 & 1.45 & 1.17 \\
\hline Ukraine & 0.04 & 0.04 & 0.04 & 0.04 & 0.04 & 0.05 \\
\hline
\end{tabular}

Source: based on data INTRACEN [9]

In 2000-2010 the world production stood at $73 \%$ on the developed countries and the share of the developing economies (including China) was 27\%. By 2015 the balance of forces changed and the share of the developed countries were only $54 \%$ of the world production. The share of China in world production grew from 7\% in 2000 to $20 \%$ in 2017. Important aspect for the developed countries is industry share decrease in economy where according to World bank data [10] the industry share (including construction) in GDP decreases every year and stands at $31.95 \%$ in $1995,28.7 \%$ in 2000 , and $25.4 \%$ in 2017.

Actually, the growth of industrial production decreases in contrast to the financial sphere where leading actors are interested in globalization. It isn't surprising that such tendency of economic deindustrialization in highly developed countries generated a counter, counteracting trend. A special sharpness to this process can give its timing with the fourth industrial revolution. It is known that the substance of the fourth industrial revolution lies in penetration of the Internet and other information technologies into the sphere of the industrial production that means in the long term practically its full automation. The most important directions of the fourth industrial revolution are the industrial Internet of things, cloudy calculations, the virtual enterprises etc. [11-12]. Now "the digital economy" grows at rates about $12 \%$ a year that can lead in the long term to creation of completely automated industrial production in which contact between various automated divisions is kept automatically on the Internet.

The term "Industry 4.0" indicating the fourth industrial revolution, involves creating by connection of machinery and information systems of such intellectual networks of new type which are capable not only to capture all value chain, circulations and consumption, but also to provide such selfregulation of these complex processes at which separate links of this chain can operate with each other independently - i.e. decentralized orders can be given to each other in real time with minimum human intervention or without participation at all.

It means transition to extremely flexible intellectual integration of the industrial production (and also circulation and consumption of industrial products) on the basis of "cloud". Thus, network machinery and production systems will be able to communicate and process information independently for autonomous management by industrial productions on the basis of a self-regulation [13]

The main disadvantage of possible impact of this new industrial revolution are risks, which are related to technological unemployment and influence of the fourth industrial revolution on macroeconomic equilibrium, i.e. on a problem of selling of manufactured goods in domestic and foreign markets [14].

During the fourth industrial revolution in the conditions of the full automation of production, the payroll has a trend toward zero that inevitably calls into question chances of product sales of an automated technology in the advanced countries domestic market. This fundamental question in the long term can bring special sharpness to problems of international trade in the $21 \mathrm{st}$ century, stimulating strengthening of the state intervention and the beginning of a new historical cycle. In such context, transition from the second to the third historical cycle in development of international trade can gain very conflict nature, as the states will be forced to actively join the fight of the countries for the world market in which they can run into each other.

\section{DISCUSSION}

The sharpness of this perspective hasn't been recognized in economic literature fully yet, in the same way as the need of cyclic approach to the analysis of international trade evolution isn't fully considered. At the same time it should be noted that the fundamental problem of product sales in domestic and foreign markets concerns not only economic prospects of the fourth industrial revolution, but also in general all historical process of increase in labor productivity on the basis of new equipment, technology and the organization of production which was developing consistently throughout the previous industrial revolutions.

Dynamic conditions of the complete product sales in terms of technical progress which is followed by increase in labor productivity, is the main condition of retaining in the 
course of economic growth of a constant share of wages for workers in national income. But it is also in modern conditions should also be based on key innovation in vocational guidance in the labor market [15], [16].

For this purpose, it is necessary that the growth of the real wage corresponded to increase in labor productivity. But in fact this condition of realization in the advanced countries, as a rule, is practically not satisfied. The growth of real wage actually lags behind increase in productivity of work, and the wages share in national income tends to decrease [14]. Nevertheless, the industrial economy throughout two centuries continued to develop on average at such unprecedentedly rapid rate which preindustrial society hasn't known. The second half of the 20th century in the advanced countries shows formation of "consumer society" and the social state which contributed to increase of the real wage. It allowed the industrial countries to solve distribution problems in many ways due to expansion of own domestic market. Increase in the real wage lowered profit margins in the advanced countries. It stimulated a wave of the liberal globalization. It sharply slowed down the growth of real wage and expansion of domestic market in advanced economy, but promoted increase in rate of return. The neoliberal dismantling of the social state has also slowed down further expansion of domestic market of the advanced countries.

On the other hand, in the course of economy globalization the world market was filled with rather cheap industrial output from developing countries. Thus, on the one hand, in the conditions of globalization falling of a share of the salary sharply amplified in national income of the advanced countries, and on the other hand - as a result of industrialization of China and other developing countries of Asia traditional sales channels of surplus of the industrial output of the advanced countries in foreign markets were actually blocked. Thus, at different stages of the historical evolution the advanced economy compensated the immanent shortage of cumulative demand in various ways.

In 21 st century and at the beginning of the 20th century such compensation was in many respects related to foreign trade, in the second half of the 20th century - to the social state and a building of "consumer society". However, the prospects of further compensation of this demand shortage seem to be extremely unsettled in both domestic markets of the advanced countries and foreign markets as well. At the same time, it is necessary to consider that channels of international trade are already filled with rather cheap industrial output from developing countries. As a result, chances of surplus selling of the industrial output in the advanced countries in foreign markets are actually blocked.

\section{CONCLUSION}

The fourth industrial revolution in the long term can bring the beginning of the third historical cycle in development of international trade not less intense and conflict character, than in the period of those historical shocks, which accompanied the beginning of the second cycle in the XX century. The carried-out analysis of such two cycles shows that now we are on the threshold of a new, third historical cycle, which can begin along with deepening of globalization crisis and transition to protectionist regulation. Change of phases of the active state regulation and the liberal deregulation was caused by transition to the free competition, but strengthening of a role of the multinational companies and their market power led to protectionism that characterizes the beginnings of the third historical cycle. The main practical conclusion for Ukraine is first of all related to a possibility of negative impact of neomercantilist turn in world trade on domestic economy that demands diversification of economy. The main prospects of the study are: firstly, the further development of the proposed methodology of a cyclical approach to the analysis of the patterns of development of international trade; secondly, the use of this methodology in order to justify practical recommendations for the economic policy of Ukraine and, finally, thirdly, the study on this basis of specific ways to diversify the Ukrainian economy, necessary for its adaptation to new conditions associated with the beginning of the next historical cycle in development international trade. Thus, the analysis of trends of international trade development and its state regulation in XXI century leads to conclusion that the priorities of economic policy of Ukraine need to be changed as follows: the foreground of technological modernization and structural transformation of national economy along with export opportunities there is an import substitution.

\section{REFERENCES}

[1] A. Galchynsky, and V. Geyets, Strategy of the economic and social developments of Ukraine (the years 2004-2015). Kyiv, 2004.

[2] V. Koval, G. Duginets, O. Plekhanova, A Antonov, and M Petrova,"On the supranational and national level of global value chain management." Entrepreneurship and Sustainability Issues, vol. 6, no. 4, pp.1922-1937, 2019.

[3] S.Suranovic, International Trade: Theory and Policy. Wash.: Saylor Foundation, 2015

[4] A.Landau, The International Trade System. NY: Routledge, 2012.

[5] P. Guerrieri, Technology and internationaltrade performance in the most advanced countries. Berkeley: University of California, 2008.

[6] R.C. Feenstra,and A.M. Taylor, International Economics. New York: Worth, 2014.

[7] A.Smith, and E. Cannan, An inquiry into the nature and causes of the wealth of nations. London: Methuen, 1922

[8] H. Qunhui, China's Industrialization Process. Singapore: Springer Singapore, 2018.

[9] INTRACEN. "International Trade Statistics," 2016. http://www.intracen.org/itc/market-info-tools/trade-statistics.

[10] World Bank, World Development Indicators. Industry (including construction), value added (\% of GDP), 2016. [Online]. Available:https://data.worldbank.org/indicator/NV.IND.TOTL.ZS. Accessed on: July 12, 2019

[11] A. McAfee, and E.Brynjolfsson, Human Work in the Robotic Future: Policy for the Age of Automation. Foreign Affairs, 2016.

[12] M. Kenney, and J. Zysman, "The Rise of the Platform Economy." Issues in Science and Technology, vol. 32, no. 3, pp. 61-69, 2016.

[13] J. Weiss, The Economics of Industrial Development. NY Taylor \& Francis, 2010

[14] T. Odinokova, M. Bozhinova, and M. Petrova, "Promotion of Innovative Entrepreneurship Under Sustainable Development", E3S Web Conferences, vol. 41, 04015, 2018.

[15] V. Koval, Y. Polyezhaev, and A. Bezkhlibna, "Communicative competences in enhancing of regional competitiveness in the labour market", Baltic Journal of Economic Studies, vol. 4, no. 5, pp.105113, 2018.

[16] J. Drobnic, "The key innovations in career guidance on labour market", Economics. Ecology. Socium, 3(1), pp. 12-22, 2019. 